\title{
Probiyotikler ve Yara İyileşme Sürecine Etkileri: Anjiyogenez Üzerine Etki Mekanizması
}

\author{
Probiotics and Their Effects on Wound Healing: The Effect Mechanisms on Angiogenesis
}

\author{
Nesli Ersoy ${ }^{1}$, Aylin Açıkgöz ${ }^{2}$, Taner Özgürtaş ${ }^{3}$
}

Geliş tarihi/Received: 14.09.2018 • Kabul tarihi/Accepted: 21.11.2018

\section{ÖZET}

Probiyotikler, gastrointestinal sistem hastalıklarından depresyona kadar çok sayıda hastalık grubunda çalışılmış ve bu hastalıklar üzerinde probiyotiklerin olumlu etkiler gösterebildiği bildirilmiştir. Probiyotiklerin bildirilen olumlu etkilerini, hastalık gelişimi ve tedavi sürecinde canlı mikrobiyotasını zenginleştirerek gerçekleştirdiği düşünülmektedir. Yara iyileşmesi ise birçok farklı mekanizmanın etkisi altında bulunan bir süreçtir. Bakterilerin bu süreçte yararlı etkileri olduğu gibi farklı bakteri türlerine bağlı olarak olumsuz etkileri de olabilmektedir. Son yapılan çalışmalarda bazı probiyotik bakteri türlerinin topikal uygulaması ya da sistemik etkileri ile yara iyileşmesi üzerinde etkili olduğu saptanmıştır. Özellikle gastrik ülserler üzerinde yapılan çalışmalarda probiyotik bakterilerin antibiyotikler ile karşlaştırıldığında, antibiyotik direncinin olduğu durumlarda anjiyogenez üzerinden etki ederek daha etkili sonuçlar gösterdiği belirtilmiştir. Probiyotiklerin etki mekanizmaları ve hangi bakteri türlerinin etkin olduğuna dair daha fazla çalışma yapılması gerekmektedir.

Anahtar kelimeler: Probiyotikler, yara iyileşmesi, anjiyogenez

\begin{abstract}
Probiotics have been studied in a large number of disease groups from gastrointestinal system disorders to depression, and it has been reported that they may have positive effects in the aforementioned diseases. The reported positive effects of probiotics are thought to be achieved by enriching the living microbiota during disease development and treatment. Wound healing is a process that is under the influence of many different mechanisms. Bacteria may have beneficial or adverse effects in this process according to their species. Recent studies have shown that some probiotic bacterial strains are effective on wound healing with topical application or by their systemic effects. It has been reported that probiotic bacteria are more effective than antibiotics, particularly in gastric ulcers with antibiotic resistance, by their actions on angiogenesis. Further studies are needed to determine the mechanisms of effect of probiotics and which species of bacteria are effective.
\end{abstract}

Keywords: Probiotics, wound healing, angiogenesis

\section{GíRiş}

Probiyotikler, konakçı mikroflorasını zenginleştirerek, sağlığın gelişmesine katkıda bulunan canlı organizmalardır. Laktobasillus ve bifidobakteryumlar, probiyotik kültürlerin en sık kullanılan türleridir ve bu türlerin, patojenik bakterilerle antagonist etkileşimleri bulunmaktadır (1). Vücuttaki bakteri
1. İletişim/Correspondence: Hacettepe Üniversitesi, Sağllk Bilimleri Fakültesi, Beslenme ve Diyetetik Bölümü, Ankara, Türkiye

E-posta: nesli.arpaci@hacettepe.edu.tr • • https://orcid.org/0000-0003-0391-8848
2. Hacettepe Üniversitesi, Sağlık Bilimleri Fakültesi, Beslenme ve Diyetetik Bölümü, Ankara, Türkiye - @ https://orcid.org/0000-0002-8847-9305

3. Sağlık Bilimleri Gülhane Üniversitesi, Tıp Fakültesi, Tıbbi Biyokimya Anabilim Dall, Ankara, Türkiye • — https://orcid.org/0000-0003-1110-6671 
sayısının, toplam hücre sayısından 10 kat daha fazla olduğu belirtilmektedir (2). Probiyotikler ayrıca vücudun farklı bölgelerinde farklı yoğunluklarda bulunmaktadırlar. Örneğin, midedeki bakteri sayısı $10^{3}$ iken, probiyotiklerin vücutta en yoğun bulundukları yer olan kolondaki sayıları 1011-1012 arasindadır. Gastrointestinal kanalda 100-1000 farklı bakteri türü bulunmaktadır (3). Yetişkin bir bireyin intestinal mukozasının, yaklaşık olarak $250 \mathrm{~m}^{2}$ uzunluğunda olduğu, ve mukozada 17 familya, 45 tip ve 500 türden oluşan bir bakteri topluluğu olduğu belirtilmektedir. $\mathrm{Bu}$ topluluğun çoğunluğunu (\%97) anaerobik bakteriler, geri kalan kısmını (\%3) ise aerobik bakteriler oluşturmaktadır. Anaerob bakteriler çoğunlukla bacteroides, bifidobacteria, eubacteria, fusobacteria, clostridia ve lactobasilli türleridir (4). Aynı zamanda vücudun farklı bölgelerindeki bakteri türleri de farklılık göstermektedir. Firmicutes ve Bacteriodetes türleri gastrointestinal kanalda bulunurken, Proteobacteria ve Actinobacteria çoğunlukla ciltte ve Proteobacteria aynı zamanda hava yolunda da bulunmaktadır (5).

Mikroflora zenginliği birçok etmenden etkilenmektedir. Doğum şekli, antibiyotik kullanımı, yaş, egzersiz, beslenme, genetik, stres ve hamilelik gibi etmenler bireylerin mikrobiyotasını etkileyen başlıca etmenler olarak gösterilmektedir (2). Probiyotik bakteriler $\mathrm{pH}$, gastrik ve pankreatik sıvılar, safra ve intestinal mukoza gibi etmenlere karşı duyarlıdır ve uygun koşullar sağlanmadığında aktivitelerini kaybetmektedirler. Bu nedenle probiyotikler ile yürütülen çalışmalar çoğunlukla bakterilerin stabilitelerinin sağlanmalarına yöneliktir (3).

Günümüzde probiyotik olarak tanımlanan organizmalar şu şekildedir: Lactobacillus ( $L$. plantarum, L. paracasei, L. acidophilus, L. casei, L. rhamnosus, L. crispatus, L.gasseri, L. reuteri, L. Bulgaricus), Propionibacterium (P. jensenii, $P$. freudenreichii), Peptostreptococcus (P. productus), Bacillus (B. coagulans, B. subtilis, B. laterosporus), Lactococcus (L. lactis, $L$. reuteri, $L$. rhamnosus, $L$. casei, L. acidophilus, L. curvatus, L. plantarum), Enterococcus (E. faecium), Pediococcus (P. acidilactici,
P. pentosaceus), Streptococcus (S. sanguis, S. oralis, S. mitis, $S$. thermophilus, $S$. salivarius), Bifidobacterium (B. longum, B. catenulatum, B. breve, B. animalis, $B$. bifidum), Bacteroides (B. uniformis), Akkermansia (A. muciniphila), Saccharomyces (S. boulardii) (3).

Probiyotiklerin canlı mikroflorasını zenginleştirdiği ve bu yolla bazı hastalıkların önlenmesi ve iyileştirilmesinde olumlu etkilerinin olduğu belirtilmiştir. Probiyotikler immün sistemde ve irritabl bağırsak sendromu, obezite, alerji ve kanser gibi hastalıkların gelişiminde etkili olan inflamatuvar süreçler gibi birçok mekanizmada düzenleyici olarak rol oynamaktadır (3). Aynı zamanda, tip 1 diyabet, romatoid artrit, ateroskleroz, hipertansiyon ve kardiyovasküler hastalık gelişim basamaklarında etkili oldukları ve probiyotik desteğinin diyare ve üst solunum yolu enfeksiyonu gibi akut durumlarda da hastalığın görülme sıklığı ve süresini azaltabildiği belirtilmektedir (6). Probiyotiklerin gastrointestinal kolik, akut enfeksiyon diyare, inflamatuvar bağırsak sendromu, antibiyotik kullanımina ve seyahate bağlı diyare ile laktoz intoleransı gibi bağırsak hastalıklarında güvenli bir şekilde kullanılabileceği bildirilmektedir (7). Aynı zamanda intestinal mikrobiyotanın bazı besin ögelerinin emilimi ve sentezinde rolü olduğu düşünülmektedir (8). Bu derleme makalenin amacı, çok sayıda farklı kullanım alanı olan probiyotik bakterilerin anjiyogenez ve yara iyileşmesi üzerine etkilerine güncel çalışmalara yer vermektir.

\section{Anjiyogenez}

Ameliyat öncesi dönemde sıklıkla görülen stres durumunun da mikrobiyota üzerinde etkili olabileceği söylenebilir. Stres durumunun kortikotropin, kortizol, noradrenalin, adrenalin ve dopamin gibi hormon düzeylerini etkilediği ve mikrobiyota dengesizliğine neden olduğu belirtilmektedir (2). Bu nedenle planlı cerrahi müdahale öncesi dönemlerde probiyotik desteğinin yara iyileşmesi, antibiyotik kullanımı ve hastanede kalış süresini azaltabileceği düşünülebilir. Probiyotiklerin yara iyileşme sürecine etkisi Şekil 1'de özetlenmiştir (5). 


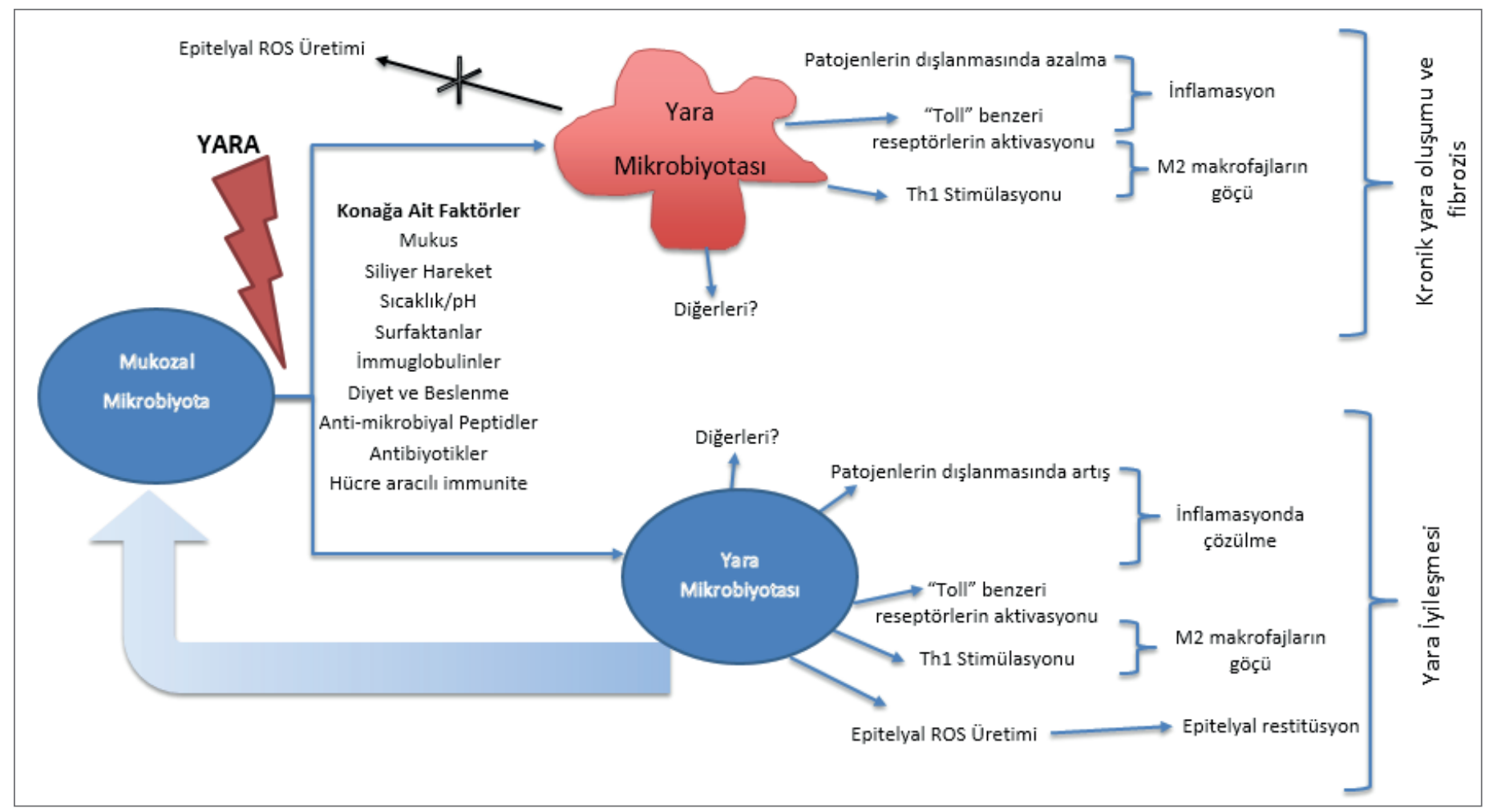

Şekil 1. Probiyotiklerin yara iyileşme sürecine etkisi: Konağa ait farklı etmenlerin varlığı, yara mikrobiyotası üzerinde olumlu veya olumsuz gösterdikleri etkiler ile kronik bir yara oluşumu veya yara iyileşmesine neden olabilmektedirler. ROS: Reaktif Oksijen Türleri, Th1: T helper 1 (5)

Yara iyileşmesinde probiyotik kullanımına ilişkin yan etkilerden en önemlisi probiyotiklerin Gís’te gaz oluşumuna neden olması ve bu nedenle batın yaralanması olan bireylerde kullanımının mümkün olmamasidir (9).

\section{Probiyotiklerin Anjiyogenez Üzerine Etkileri}

Probiyotiklerin anjiyogenezüzerindeetkigösterdikleri ve bu yol üzerinden yara iyileşmesine yardımcı olduğu düşünülmektedir (10,11). Probiyotiklerin anjiyogenez üzerine potansiyel etki mekanizmaları şu şekildedir: (a) inflamatuvar sitokin profilini düzenlemek, (b) proinflamatuvar basamağın downregülasyonu veya epitel bariyer işlev gelişimi ile viseral hipersensitiviteyi azaltmak, (c) spinal afferent iletimini sağlamak ve (d) stres yanıtı gibi durumlarda düzenleyici etki göstermek (3).

Gastrointestinal kanalda vasküler endotelyal büyüme faktör (VEGF) reseptörü sinyalizasyonu ile inflamatuvar süreçte anjiyogenezin oluşumunda etki gösterdiği belirtilmektedir (3). Anjiyogenez yolu ile VEGF yeni mikrovesel oluşumu ve granüle doku formasyonunu stimüle etmektedir. Anjiyogenezin stimülasyonu ise duodenal ve gastrik ülserlerde yara iyileşmesini sağlayıcı etki göstermektedir (11). Yapılan bir çalışmada, sekiz farklı bakteri karışımından oluşan probiyotik kültürün [Lactobacilli (acidophilus, bulgaricus, casei, plantarum), Bifidobacteria (breve, infantis, longum) ve Streptococcus] VEGF yolu ile anjiyogenezi arttırdığı, gastrik ülserlerde yara iyileşmesi üzerine istatistiksel olarak anlamlı şekilde olumlu etki gösterdiği bildirilmiştir (10). Gastrik onarım ve ülser iyileşmesinde ise EGF reseptörü yardımcı olmaktadır. Bunun dağılımı önemli bir proliferasyon alanı oluşturmakta, birleşik olduğu kapiller ile hem anjiyogenezi hem de hücre farklılaşmasını sağlamaktadır. Probiyotiklerin bu büyüme faktörlerinin ekspresyonlarını arttırarak gastrik ülserlerin iyileşmesine yardımcı olduğu belirtilmektedir (11). Yapılan bir çalışmada, Saccharomyces boulardi'nin hem in vivo hem de 
in vitro ortamda epitel hücrelerde 21 integrin kollajen reseptörünü aktive ederek anjiyogenezi sağladığı bildirilmiştir (12). Lam ve arkadaşlarının (11) çalışmasında ise L. rhamnosus GG'nin hücre farklılaşması ve anjiyogenezi arttırdığı ve hücre apoptozisini azalttığı, bu yolla gastrik ülserlerde iyileşmeye yardımcı olduğu belirtilmiştir. Ek olarak iyileşme sürecinin bakteri sayısı ile ters orantılı olduğu bildirilmiştir (11).

Yapılan bir çalışmada, lactobacillus acidophillus'un iki farklı suşunun (ATCC 4356 ve 443121) topikal uygulamasinın, tümör nekrozis faktör- $\alpha$ (TNF-a), interlökin ve interferon gibi diğer sitokinlerin üretimine ek olarak polimorfonükleer lökosit (PMN) ve makrofajların kemoatraksiyonu ve anjiyogenezini sağladığı belirtilmiştir (13). Bir başka çalışmada L.brevis ve L.plantarum'un yara iyileşmesi sürecine etkisi araştırılmış, 21 gün sonunda probiyotik uygulanan farelerde enfeksiyon görülmemiş ve yara iyileşme sürecinin kontrol grubuna göre daha kısa olduğu gözlenmiştir (14). Yanık hastaları üzerinde yapılan bir başka çalışmada ise $L$. plantarum'un topikal uygulamasinın, silver sulphadiazine tedavisine alternatif olabileceği belirtilmiştir (15). Yara iyileşmesinde çok farklı kimyasal ajanlar kullanılmakta ancak çoğunun yan etkileri bulunduğu da bildirilmektedir (14).

\section{Probiyotiklerin Gastrik Ülserde Yara İyileşmesi Üzerine Etkileri}

Gastrik mukoza tek katlı epitel hücrelerden oluşmakta ve sadece kendi salgı ve enzimlerine maruz kalmamaktadır. Gastrik mukozanin duodenal safra, Helicobacter phylori (H. pylori), alkol ve non-steroidal anti-inflamatuvar ilaçlarla temas etmesi, mukozada hasara yol açmaktadır. İnsidansı oldukça yüksek olan gastrik ülserler, mide mukozasında yırtılma, kanama ve gastrik kanserle ilişkilendirilmektedir (16). Yapılan çalışmalarda probiyotik desteğinin gastrik ülserde yara iyileşmesi olumlu etki gösterdiği belirtilmektedir $(1,11)$. Hatta Singh ve Kaur (1) çalışmalarında L. acidophilus'un sinbiyotik bir ajanla birlikte kullanımının, gastrik ülserlerde terapötik etkisi olduğunu göstermiştir.
Gastrik ülserin probiyotikler ile iyileştirilebileceği ilk olarak 1998 yllında Elliott ve ekibi tarafindan gösterilmiştir. Aynı çalışmada araştırmacılar Lactobacillus türü probiyotiklerin antibiyotik kullanımını azaltabileceğini ve özellikle antibiyotik direncinin olduğu durumlarda daha da etkili olabileceğini belirtilmişlerdir (7). Benzer şekilde yoğurt gibi fermente süt ürünleri tüketiminin gastrointestinal sistemde olumlu etkilerinin olduğu da bilinmektedir (16). Ayrıca ratlar üzerinde yapılan bir çalışmada, ibuprofenin neden olduğu gastrik mukoza hasarının Saccharomyces boulardi tarafindan tedavi edildiği bildirilmiştir (17).

Gastrik ülserlerde yara iyileşmesi epidermal büyüme faktörü, hepatosit büyüme faktörü, insülin benzeri büyüme faktörü 1, trefoil faktörleri, siklooksigenaz 2'den üretilmiş prostoglandin ve bazı sitokinlerin denetiminde gerçekleşmektedir. Yara iyileşmesini aynı zamanda hipoksi, vasküler endotelyal büyüme faktörü, fibroblast büyüme faktörü ve anjiyopoetinin neden olduğu anjiyogeneze de ihtiyacı bulunmaktadır (16). Probiyotiklerin mide duvarı hücrelerinde protein ekspresyonunu etkilediği, yeni damar oluşumunu desteklediği ve bu yolla ülserin iyileşmesinde olumlu etkilerinin olduğu belirtilmiştir. Buna ek olarak probiyotiklerin, kolonda kısa zincirli yağ asidi üretimine katkıda bulunarak gastrointestinal duvarın kanlanmasını ve mukozal hücrelere besin ögesi ulaşımını sağladığı da vurgulanmıştır (18).

\section{Probiyotiklerin Cilt Yaralarının İyileşmesi Üzerine Etkileri}

Ciltte kalıcı ve geçici türde birçok mikrobiyal tür bulunmaktadır. Proprionibacteria ( $P$. acnes, $P$. avidum ve $P$. granulosum), Koagülaz negatif Staphylocci (Staphylococcus epidermidis), Micrococci, Corynebacteria ve Acinetobacteria ciltteki kalıcı tür mikrobiyal bakterilere örnektir. Staphylococcus aureus, Escherichia coli, Pseudomonas aeroguinosa ve Bacillus türleri ise geçici tür mikrobiyal türlerdir. Sağlıklı bir cilt işlevi için koruyucu mikrofloranın önemli olduğu bilinmektedir (8). Cilt, vücudun ilk immün bariyeri olarak görev almakta ve cilt bütünlüğünün büyük ölçüde bozulması, ciltte 
yaralanmalara neden olmakta hastalıkların başlangıcında olduğu gibi iyileşme mekanizmalarının devreye girmesine neden olmaktadır. Akut yaralanmalarda iyileşmenin desteklenmesi, kronik yaralarda ise enfeksiyon riskinin en aza indirilmesi, tedavide temel amaç olarak karşımıza çıkmaktadır (14).

Yara iyileşmesi doğal fizyolojik bir süreçtir ve mikroflora bu süreci hem olumsuz hem de olumlu yönde etkileyebilecek önemli etmenlerden birisidir (19). Yara ya da yanık durumunda cilt bariyerindeki bozulmalar nedeniyle bakteriyal kolonizasyon oluşmakta ve enfeksiyona açık bir durum ortaya çıkmaktadır (9). Yara, stres yaratan bir durumdur ve kortizol, epinefrin, norepinefrin, asetilkolin,katestatin, substant $\mathrm{P}$ ve a-melanotropin gibi nöroendokrin ve stres aracilarınin salgilanmasına neden olmaktadır. $\mathrm{Bu}$ moleküller enfeksiyon riskini arttırmakta ve yara iyileşmesini zorlaştırmaktadır. Yara iyileşmesi, homeostaz, inflamasyon, proliferasyon ve yeniden yapılanma süreçlerini içermektedir. İlk basamak olan homeostazda plateletler aktive edilmekte, büyüme faktörleri, sitokinler ve plateletlerde bulunan maddeler salgllanmaktadır. Bu moleküller kemotaksis, hücre proliferasyonu, anjiyogenez, ekstraselüler matriks birikimi ve yeniden doku yapılanması gibi mekanizmaları aktive etmektedir (20).

Yara iyileşmesinde ornitin dekarboksilaz (ODC), VEGF, B-hücre lenfoma 2 (Bcl-2) ve epidermal büyüme faktör reseptörü (EGF reseptör) gibi çeşitli büyüme faktörlerinin ekspresyonunun etkili olduğu belirtilmektedir (11). Probiyotiklerin bu mekanizmaları etkileyerek yara iyileşmesinde etkili olduğu belirtilmektedir. Aynı zamanda, bakteriyal aktivitenin ciltte $\mathrm{pH}$ ve osmotik dengeyi etkileyebileceği bildirilmektedir (8). Yara iyileşmesi sürecinde etkili olan bakteri isimleri Tablo 1'de verilmiştir (5).

Tablo 1. Yara iyileşmesi ile ilgili bakteriler ve olası ilişkileri

\begin{tabular}{|c|c|}
\hline Yara iyileşmesi ile ilgili bakteriler & Olası ilişkiler \\
\hline Streptococcus spp. & Kronik diyabetik yaralarda iyileşme insidansı yüksektir. \\
\hline $\begin{array}{l}\text { Staphylococcus aerueus } \\
\text { Staphylococcus epidermidis }\end{array}$ & $\begin{array}{l}\text { Kronik diyabetik yaralarda insidansı yüksektir. Kolonizasyon yara iyileşmesi sürecine zarar } \\
\text { verebilir. Yaradan kolayca kültüre olabilir. }\end{array}$ \\
\hline Enterococcus spp. & Kronik diyabetik yaralarda insidansı yüksektir. \\
\hline Peptostreptococcus spp. & Kronik diyabetik yaralarda insidansı yüksektir. \\
\hline Bacteroides spp. & Kronik diyabetik yaralarda insidansı yüksektir. \\
\hline Prevotella spp. & Kronik diyabetik yaralarda insidansı yüksektir. \\
\hline Pseudomonas aeruginosa & $\begin{array}{l}\text { Kronik diyabetik yaralarda insidansı yüksektir. Germ-free fare yarasına aşılanması ile yara } \\
\text { iyileşmesi hızlanmıştır (reepitelizasyon, epitel hücre farklılaşması ve neo-vaskülerizasyon). } \\
\text { Yaradan kolayca kültüre olabilir. }\end{array}$ \\
\hline Lactobacillus spp. & $\begin{array}{l}\text { GI kanalda, yara iyileşmesi sürecinde hücre göçü ve epitelyal restitüsyonun düzenleyebilen, } \\
\text { ekstraselüler sinyal regüle edici kinazların fosforilasyonunu indükler. }\end{array}$ \\
\hline Lactobacillus reuteri strain $R C-14$ & $\begin{array}{l}\text { Bakteri suşuna özgü davranış şeklinde diğer türlerin (örneğin, staphylococcus aureus) } \\
\text { kolonizasyonunu engeller. }\end{array}$ \\
\hline Escherichia coli & $\begin{array}{l}\text { Gİ kanalda gelişen durum, epitelyal hasara bağlı olarak artan inflamasyon ortamında } \\
\text { oluşabilir.Yaradan kolayca kültüre olabilir. }\end{array}$ \\
\hline Klebsiella pneumoniae & $\begin{array}{l}\text { Gİ kanalda gelişen durum, epitelyal hasara bağlı olarak artan inflamasyon ortamında } \\
\text { oluşabilir. Farelerde bulaşıcı spontan kolitin indüklenmesinde önemlidir. }\end{array}$ \\
\hline Proteus mirabilis & Farelerde bulaşıcı spontan kolitin indüklenmesinde önemlidir. \\
\hline Corynebacteria spp. & Yaradan kültürlenebilir. \\
\hline Propionbacteria spp. & Yaradan kültürlenebilir. Ancak sağlıklı ciltte bulunduğundan daha düşük düzeyde bulunur. \\
\hline Neisseria spp. & Çoğunlukla yarada bulunan zor gelişen ve anaerobik bakteri \\
\hline Campylobacteria spp. & Çoğunlukla yarada bulunan zor gelişen ve anaerobik bakteri \\
\hline Clostridiaceae & Çoğunlukla yarada bulunan zor gelişen ve anaerobik bakteri \\
\hline
\end{tabular}

Gí: Gastrointestinal 
Yara enfekte olduğunda antimikrobiyal ajanlar kullanılmakta, bazı durumlarda bu ajanlar etkili olamamaktadır (19). Probiyotik desteğinin enfeksiyon sıklığını ve hastanede kalış süresini azalttığı ve bu tedavilere eklenebileceği bildirilmiştir. Pediatrik termal yanıklar üzerinde yapılan bir çalışmada, probiyotik desteğinin immünoglobülin A ve toplam lenfosit sayısını arttırdığı, C reaktif protein (CRP) düzeyini düşürdüğü saptanmıştır (9). Probiyotiklerin dolaylı yoldan yara iyileşmesini etkilediği de belirtilmektedir. $\mathrm{Bu}$ konu ile ilgili yapılan bir çalışmada, oral mikrofloranın besin kaynaklı nitratları
$\left(\mathrm{NO}_{3}^{-}\right)$içerdiği ve dolaylı yoldan kan basıncını düşürerek yara iyileşmesi sürecini uzattığı, mikroflora temizliği yapıldığında ise tam tersi mekanizma ile yara iyileşmesi sürecini kısalttığı belirtilmiştir (21).

Yukarıda anlatılanlara ek olarak, bilindiği gibi obezite, hiperlipidemi, diyabet ve hipertansiyon gibi metabolik sendrom bileşenlerinde yara iyileşmesi oldukça zor olmaktadır (20). Bu grup hastalarda yapılacak olan çalışmaların hastaların yaşam kalitesini de arttıracağı düşünülmektedir. Şu an ülkemizde satışı olan probiyotik ürünlerin içerdikleri aşağıda verilmiştir (22-24).

Tablo 2. Ülkemizde satışı olan probiyotik ürünler ve içerikleri

\section{Ticari ürün adı}

NBL (Probiotic ATP)

NBL Probiotic Gold

NBL Gynobiotic

Solgar Advanced Multi-Billion Dophilus

Solgar Advanced 40+ Acidophilus

Solgar Advanced Acidophilus Plus

Bactovis

\section{İçermiş olduğu probiyotik bakteri isimleri}

Lactobacillus casei

Lactobacillus rhamnosus

Lactobacillus plantarum

Bifidobacterium lactis

Lactobacillus acidophilus

Enterococcus faecium

Lactobacillus plantarum

Bifidobacterium lactis

Streptococcus thermophilus

Bifidobacterium longum

Lactobacillus acidophillus

Lactobacillus rhamnosus

Enterococcus faecium

Bifidobacterium bifidum

Bifidobacterium longum

Lactobacillus acidophilus

Lactobacillus rhamnosus

Acidophilus LA-5

B Laktis, BB-12

Lactobacillus paracasei

Phamnosus GG,LGG

Acidophilus LA-5

Lactobacillus rhamnosus

Lactobacillus paracasei

$B$ laktis, $B B-12$

Streptococcus thermophilus

Acidophilus LA-5

B laktis, BB-12

Lactobacillus acidophilus- LA-5

Bifidobacterium- BB-12

Streptococcus thermophilus- STY-31 ${ }^{T M}$

Lactobacillus delbrueckii ssp. bulgaricus- LBY-27 $7^{T M}$ 


\section{SONUÇ VE ÖNERILER}

Probiyotiklerin yara iyileşmesindeki kullanımının, anjiyogenez üzerine olası etkileri ile iyileşme sürecini hızlandırabileceğine dair bazı kanıtlar olsa da, VEGF ekspresyonunu arttırdığı mekanizmanın hala belirsizliğini koruduğu ve bu konuda daha fazla çalışmaya gerek duyulduğu belirtilmektedir. Aynı zamanda obezite, hiperlipidemi, diyabet ve hipertansiyon gibi metabolik sendrom bileşenlerinde

\section{KAYNAKLAR}

1. Singh PK, Kaur IP. Synbiotic (probiotic and ginger extract) loaded floating beads: a novel therapeutic option in an experimental paradigm of gastric ulcer. J Pharm Pharmacol 2012;64(2):207-17.

2. Cerdá B, Pérez M, Pérez-Santiago JD, Tornero-Aguilera JF, González-Soltero R, Larrosa M. Gut microbiota modification: another piece in the puzzle of the benefits of physical exercise in health? Front Physiol 2016;7:51.

3. Kerry RG, Patra JK, Gouda S, Park Y, Shin H-S, Das G. Benefaction of probiotics for human health: A review. J Food Drug Anal 2018.

4. Caramia G, Atzei A, Fanos V. Probiotics and the skin. Clin Dermatol 2008;26(1):4-11.

5. Scales BS, Huffnagle GB. The microbiome in wound repair and tissue fibrosis. J Pathol 2013;229(2):323-31.

6. Counsell K. How diet, exercise, and probiotics influence diversity in gut microbiota. Big Sky Undergrad J 2015;3(1):8.

7. Elliott SN, Buret A, McKnight W, Miller MJ, Wallace JL. Bacteria rapidly colonize and modulate healing of gastric ulcers in rats. Am J Physiol Gastrointest Liver Physiol 1998;275(3):G425-G32.

8. Krutmann J. Pre-and probiotics for human skin. Clin Plast Surg 2012;39(1):59-64.

9. El-Ghazely M, Mahmoud W, Atia M, Eldip E. Effect of probiotic administration in the therapy of pediatric thermal burn. Ann Burns Fire Disasters 2016;29(4):268.

10. Dharmani P, De Simone C, Chadee K. The probiotic mixture VSL\# 3 accelerates gastric ulcer healing by stimulating vascular endothelial growth factor. PLoS One 2013;8(3):e58671.

11. 11. Lam EK, Yu L, Wong HP, Wu WK, Shin VY, Tai EK, et al. Probiotic Lactobacillus rhamnosus GG enhances gastric ulcer healing in rats. Eur J Pharmacol 2007;565(13):171-9. de yara iyileşmesi oldukça zor gerçekleşmektedir. Bu grup hastalarda yapılacak olan çalışmaların da yatan hastalar için hastanede kalış süresini azaltabileceği ve hastaların yaşam kalitesini arttırmaya olan katkıları ile önemli olacağı düşünülmektedir.

Çıkar çatışması - Conflict of interest: Yazarlar çıkar çatışması olmadığını beyan ederler. - The authors declare that they have no conflict of interest.

12. Giorgetti G, Brandimarte G, Fabiocchi F, Ricci S, Flamini P, Sandri G, et al. Interactions between innate immunity, microbiota, and probiotics. J Immunol Res 2015;2015:501361.

13. Halper J, Leshin L, Lewis S, Li W. Wound healing and angiogenic properties of supernatants from Lactobacillus cultures. Exp Biol Med 2003;228(11):132937.

14. Nasrabadi H, Ebrahimi T. Comparison of the effects of Lactobacillus brevis and Lactobacillus plantarum on cutaneous wound healing in rats. Afr J Microbiol Res 2011;5(24):4226-33.

15. Peral MC, Huaman Martinez MA, Valdez JC. Bacteriotherapy with Lactobacillus plantarum in burns. Int Wound J 2009;6(1):73-81.

16. Khoder G, Al-Menhali AA, Al-Yassir F, Karam SM. Potential role of probiotics in the management of gastric ulcer. Exp Ther Med 2016;12(1):3-17.

17. Girard P, Coppé MC, Pansart Y, Gillardin JM. Gastroprotective effect of Saccharomyces boulardii in a rat model of ibuprofen-induced gastric ulcer. Pharmacol 2010;85(3):188-93.

18. Singh PK, Deol PK, Kaur IP. Entrapment of Lactobacillus acidophilus into alginate beads for the effective treatment of cold restraint stress induced gastric ulcer. Food Funct 2012;3(1):83-90.

19. Tsiouris CG, Kelesi M, Vasilopoulos G, Kalemikerakis I, Papageorgiou EG. The efficacy of probiotics as pharmacological treatment of cutaneous wounds: Metaanalysis of animal studies. Eur J Pharm Sci 2017;104:2309.

20. Tsiouris CG, Tsiouri MG. Human microflora, probiotics and wound healing. Wound Med 2017;19:33-8.

21. Kapil V, Haydar SM, Pearl V, Lundberg JO, Weitzberg E, Ahluwalia A. Physiological role for nitrate-reducing oral bacteria in blood pressure control. Free Radic Biol Med 2013;55:93-100. 
22. Ürün bilgisi. Erişim Adresi: https://www.nblprobiotic. com/. Erişim Tarihi: 30.07.2018.

23. Ürün bilgisi. Erişim Adresi: https://www.solgar.com.tr/.
Erişim Tarihi: 30.07.2018.

24. Ürün bilgisi. Erişim Adresi: https://www.anti.com.tr/ urunler/bactovis-probiyotik. Erişim Tarihi: 30.07.2018. 